\title{
ALLELOPATHIC EFFECTS OF BINDWEED (CONVOLVULUS ARVENSIS L.) ROOT EXUDATES ON PLANTS AND SOIL MICROFLORA
}

\author{
Balah, Mohamed A. \\ Plant Protection Dept., Desert Research Center, El-Matareya, Cairo, \\ Egypt \\ E-mail: maziz1974@yahoo.com, mbaziz1974@gmail.com
}

\begin{abstract}
ne of the main weeds ways to release allelochemicals is $\bigcirc$ root exudation, which is an important regulating agent in neighbor plants and microbes. The rhizosphere microbial communities were clearly rich, compared with non rhizosphere soil at both high and low density areas of filed bindweeds (Convolvulus arvensis L.). Bindweed roots exudates inhibited rhizosphere soil bacteria and fungi in high density sites than the low density ones. The $\mathrm{EC}_{50}$ of bindweed ethyl acetate root exudates extract was 1625 (Lactuca sativa L.) and $1360 \mu \mathrm{g} / \mathrm{g}$ (Phalaris paradoxa L.) for seedlings biomass fresh weights. The amount of total phenolics was higher in rhizosphere than non rhizosphere soil that ranged between 0.7 to 0.9 and 0.3 to $0.57 \mathrm{mg} / \mathrm{g}$ soil, respectively. The analysis of exudates profile has shown six compounds, namely umbelliferone $\left(\mathrm{C}_{9} \mathrm{H}_{6} \mathrm{O}_{3}\right)$, quercetin $\left(\mathrm{C}_{15} \mathrm{H}_{10} \mathrm{O}_{7}\right)$, gentisic acid glycoside $\left(\mathrm{C}_{13} \mathrm{H}_{16} \mathrm{O}_{9}\right)$, coumaric acid glycoside $\left(\mathrm{C}_{15} \mathrm{H}_{18} \mathrm{O}_{8}\right)$, vanillic glycoside $\left(\mathrm{C}_{14} \mathrm{H}_{18} \mathrm{O}_{9}\right)$ and ferulic glycoside $\left(\mathrm{C}_{16} \mathrm{H}_{20} \mathrm{O}_{9}\right)$, characterized by LC-MS. These results support the aggressiveness of bindweed in different types of soil through its suppressive effects upon associated plants and microbes through release of underground chemical signals.
\end{abstract}

Keywords: Bindweeds, exudates, allelochemicals, phytotoxicity, microbes, rhizosphere and non rhizosphere

Field bindweed (Convolvulus arvensis L.) family (Convolvulaceae) is a deep-rooted perennial weed that reproduces from seed and horizontal rhizomes (Wiese and Phillips, 1976). The number of seeds varies from 25 to 300 per plant (Weaver and Riley, 1982). Seeds can remain viable for up to 50 years (Timmons, 1949). After seed germination the vertical taproot grows directly down (Frazier, 1943). Lateral roots develop mainly in the top $30 \mathrm{~cm}$ of soil and these grow out horizontally for 35 to $100 \mathrm{~cm}$ before turning down to form secondary vertical roots. These give rise to more laterals that again turn down to form verticals and so on. At the point where laterals turn down, 
rhizomes develop from adventitious root buds and grow upwards to emerge as new shoots. Less commonly, shoots form along the horizontal portion of the lateral roots. Apart from the initial aerial shoot, all other shoots originate from root borne stem buds, which give rise to vertical underground stems or rhizomes (Maff, 1957). Convolvulus is derived from the Latin, convolere, meaning to entwine, and arvensis means 'of fields' The genus Convolvulus contains about 250 species. Convolvulus is an ubiquitous weed, but species of arvensis is understood to contain alkaloids that are toxic (Gray, 1970). Because of its wide distribution in all parts of the world with a temperate climate, abundance and economic impact, Convolvulus arvensis is considered one of the top ten 'world's worst weeds' (Holm et al., 1977). Like other weeds, field bindweed takes nutrients and water that would otherwise be available to desirable species (Frazier, 1943). It can reduce the available soil moisture in the top $60 \mathrm{~cm}$ of soil to below the wilting point for many species (Weaver and Riley, 1982). There was a significant increase in available soil water following field bindweeds control in an agricultural setting (Wiese et al., 1996). It can also be very difficult to permanently remove in residential settings. Overall, crop yields can be reduced to 50-60\% where infestations are dense (Callihan et al., 1990). In addition, they may strangle crops, delay ripening and hinder harvesting procedures (Maw, 1984). Methanol extracts of $C$. arvensis had stimulatory effect at 75,150 , and $300 \mathrm{ppm}$ and slightly inhibtory infleunce at $600 \mathrm{ppm}$ on the growth and physiological processes of wheat (Hegab and Gharieb, 2010). The methanolic extracts of $C$. arvensis had a genotoxic and inhibitor activity on the total soluble protein content of Zea mays L. (Serap et al., 2013). More recently, water soluble tropane alkaloids, calystegines, have been extracted from C. sepium and C. arvensis (Tepfer et al., 1988). Substances released by healthy and intact roots into the environment are collectively designated as root exudates. Many compounds are released by plant roots, including inorganic ions and substances, amino acids, amides, sugars, aliphatic acids, aromatic acids, volatile aromatic compounds, gases such as ethylene, vitamins, peptides, proteins, enzymes, plant hormones, alcohols, ketones, olefins, urea, phytoalexins (Grayston et al., 1996; Aulakh et al., 2001 and Paynel et al., 2001). Several recent papers have documented the antimicrobial and antifungal properties of root-secreted secondary metabolites (Walker et al., 2003). Bertin et al. (2003) noted that root exudates being the largest source of allelochemical inputs into the soil environment, may inhibit some rhizosphere microorganisms. Finally, roots exudates of field bindweed decrease germination of some crop seeds (Swan, 1980). Convolvulaceae have glycoretines, alkaloids, polyphenols and reserve carbohydrates (Hegnauer, 1964). The biochemical interactions between Solanum lycopersicum, Raphanus sativus var. radicula, Lactuca sativa and Daucus carota cultivars and Convolvulus arvensis weeds undergo through an emission of different active substances (Todorov et al., 1994). Among

Egyptian J. Desert Res., 65, No. 1, 31-46 (2015) 
different extracted parts, total parts $\left(\mathrm{P}_{\text {total }}\right)$ of bindweed had the highest inhibitory effect on millet and basil germination and growth characters. Extract concentration (AE) at $100 \%$ had the highest inhibitory effects on millet and basil germination and seedling growth as compared with control. In contrast, $\mathrm{AE}$ at $33 \% \mathrm{w} / \mathrm{v}$ had the lowest inhibitory effect on both plants (Fateh et al., 2012). There is a great deal of information on field bindweed's effects upon crops, but a little is known about bindweed root exudates impacts on naturally associated plants and microbes. The aim of this work was to investigate the effect of field bindweed root exudation on other plants and microbes within the rhizosphere as well as identify their root exudates metabolic profile.

\section{MATERIALS AND METHODS}

\section{Bindweed Root Exudate Extracts}

Field bindweed (Convolvulus arvensis L.) seeds were collected from El-frafra and El-Bahria oasis, Egypt during mature stage. Sample was identified according to Täckholm (1974) and deposited at Desert Research Center, Cairo, Egypt. Seeds were mechanically scarified (Weaver and Riley, 1982) and placed on static Murashige and Skoog (MS) basal media (Murashige and Skoog, 1962) and allowed to germinate for seven days, then seedlings with only roots submerged were transferred to tissue culture tubes contain $5 \mathrm{ml}$ MS liquid medium. After 28 days, exudates were collected from 400 seedlings and centrifuged at 10,000 rpm for 10 min to remove any cellular debris. Supernatants were passed through a nylon syringe filter of pore size $0.45 \mathrm{~mm}$ (Scientific Resources Inc.). The supernatant was subjected to refrigerator $\left(-80^{\circ} \mathrm{C}\right)$ and was concentrated by freeze dryer (Walker et al., 2003 and Apricio et al., 2008). The residues were resuspended in $50 \mathrm{ml}$ distilled water with $\mathrm{pH} \leq 4$, followed by a liquid-liquid partitioning step and phase separation by adding ethyl acetate three times (Schwab et al., 1983). The extracts were evaporated to dryness by aeration and dissolved in ethanol to give $0,500,1000,1500$ and $2000 \mu \mathrm{g} \mathrm{ml}^{-1}$ and placed in liquid MS medium, then seedling of lettuce ( $L$. sativa) and little seed ( $P$. paradoxa) were transferred to each tube, after 10 days from treatment, seedlings total biomass were recorded. The extracts were analyzed through gradient elution on a reversed phase $5 \mathrm{~mm}, \mathrm{C}_{18}$ column $(25 \mathrm{~cm} \times 4.6$ $\mathrm{mm}$ ) (Supelco, USA), using an HPLC (Dionex, USA) system consisting of P580 pumps connected to an ASI-100 Automated Sample Injector. The wavelength scan was measured by a PDA-100 Photodiode Array Detector, between 190 to $800 \mathrm{~nm}$. Mobile phase was consisted of double distilled water (Solution A) and $\mathrm{MeOH}$ (Solution B) (Fisher, USA). A multi-step gradient was applied for all separations with an initial injection volume of 20 $\mu \mathrm{l}$ and a flow rate of $1 \mathrm{ml} \mathrm{min}^{-1}$. The multistep gradient was as follows: $0-5$ 
$\min 5.0 \%$ B, 5-20 min $20.0 \%$ B, 20-40 $\min 80.0 \%$ B and 40-60 min $100 \%$ B. Molecular weight was determined by LC coupled to a Thermo Finnigan Surveyor MSQ mass spectrometer detector (USA). Mass data were collected over the range of the gradient program at a rate of one scan per two seconds. All solvents and the authentic standard chemicals were obtained from Sigma -Aldrich.

\section{Bioassay on Filter Paper}

Ten sterilized seeds of $L$. sativa and $P$. paradoxa were placed in a filter paper wetted with $5 \mathrm{ml}$ distilled water containing 0, 500, 1000, 2000 $\mu \mathrm{g} / \mathrm{ml}$ from root exudates extracts per petri dish. Each treatment was replicated five times in a completely randomized design. The dishes were left at room temperature $\left(25^{\circ} \mathrm{C}\right)$. After 10 days, the data were recorded on seed germination, root and shoot length. Inhibition percentage was calculated for each trait; $\mathrm{I} \%=[(\mathrm{C}-\mathrm{T}) / \mathrm{C})] \times 100 \%]$, Where, $\mathrm{C}$; control treatment and $\mathrm{T}$ : extract treatment.

\section{Extraction of Soil Phenols}

Soil phenolic compounds were extracted from $25 \mathrm{gm}$ sample of dried soil in $0.5 \mathrm{~N} \mathrm{HCl}$ distilled water: Methanol $(100 \mathrm{ml})$ by shaking during a 24 hour period, followed by centrifugation at $5000 \mathrm{rpm}$ for $10 \mathrm{~min}$ at $25^{\circ} \mathrm{C}$ (Chiang et al., 2006). Further purification has been carried out by applying aqueous extract on the top of resin column containing five gram from styrene-divinylbenzene copolymer (sigma-Aldrich) and eluted by ethyl acetate (Martens, 2002a). The elute evaporated to dryness and the residue dissolved in $2 \mathrm{ml}$ methanol. The Folin-Ciocalteu2 (FC) colorimetric methods were used to measure total phenols (TP).

\section{Effect of Bindweed Root Exudates on Soil Microorganism Counts}

Soil samples were collected from six distinct sites belonging to different locations; in El-Frafra (Madkhal El Frafra, Shmenda and Pier Khamsa) and El-Bahariaa (Elhieeze, El Ghaba and Gufara) Oasis, during 2013, for high and low density (HD and LD) adjacent stands of $C$. arvensis $\left(\mathrm{HD} \geq 20\right.$ plants $/ \mathrm{m}^{2}$ and $\mathrm{LD} \leq 20$ plants $/ \mathrm{m}^{2}$ ). Soil samples were subjected to physical and chemical analysis (Table 1 and 2) outlined by Richards (1954) and Black (1973). The advantaged roots were shaken several times to remove the attached rhizosphere soil particles. Five grams from rhizosphere and non-rhizosphere soils samples were taken and stored at $-4^{\circ} \mathrm{C}$ and subsequently used for microbiological analysis. The dilution plate technique (Johnson et al., 1959) was employed to enumerate the most important groups of soil fungi and bacteria. Potato dextrose agar (PDA) media and nutrient agar (NA) were used for the enumeration of fungi and bacteria, respectively. Five petri dishes were incubated at $25 \pm 1^{\circ} \mathrm{C}$ for five days for fungi and at $30 \pm 1^{\circ} \mathrm{C}$ for $24 \mathrm{~h}$ for bacteria (Parkinson et al., 1971). Data were taken from 
five replicates and readings were expressed as Colony Forming Units (CFU) /g soil.

Table (1). Site location and textural analysis of soils.

\begin{tabular}{|c|c|c|c|c|c|c|}
\hline & \multicolumn{2}{|c|}{ Location } & \multicolumn{3}{|c|}{$\begin{array}{l}\text { Particle size } \\
\text { distribution }\end{array}$} & \multirow[t]{2}{*}{ Soil texture } \\
\hline & $\begin{array}{c}\text { Latitude } \\
(\mathbf{N})\end{array}$ & $\begin{array}{c}\text { Longitude } \\
\text { (E) }\end{array}$ & $\begin{array}{c}\text { Sand } \\
(\%)\end{array}$ & $\begin{array}{l}\text { Silt } \\
(\%)\end{array}$ & $\begin{array}{l}\text { Clay } \\
(\%)\end{array}$ & \\
\hline \multicolumn{7}{|c|}{ El Frafra Oasis } \\
\hline $\begin{array}{l}\text { Madedkhal } \\
\text { El Frafra }\end{array}$ & $27^{\circ} 05^{\prime} 444^{\prime \prime}$ & $27^{\circ} 58^{\prime} 830^{\prime \prime}$ & 60.0 & 25.0 & 15.0 & Sandy loam \\
\hline Shmenda & $27^{\circ} 01^{\prime} 378^{\prime \prime}$ & $27^{\circ} 56^{\prime} 642^{\prime \prime}$ & 61.0 & 27.0 & 12.0 & Sandy loam \\
\hline Pier Khamsa & $27^{\circ} 03^{\prime} 814^{\prime \prime}$ & $27^{\circ} 55^{\prime} 470^{\prime \prime}$ & 62.0 & 24.0 & 14.0 & Sandy loam \\
\hline \multicolumn{7}{|c|}{ El-Bahariya Oasis } \\
\hline Elhieeze & $28^{\circ} 01^{\prime} 574^{\prime \prime}$ & $28^{\circ} 38^{\prime} 338^{\prime \prime}$ & 45.0 & 25.0 & 30.0 & Clay loam \\
\hline $\begin{array}{c}\text { El Ghaba } \\
\text { Gufara }\end{array}$ & $\begin{array}{l}28^{\circ} 21^{\prime} 909^{\prime \prime} \\
28^{\circ} 18^{\prime} 073^{\prime \prime}\end{array}$ & $\begin{array}{lll}28^{\circ} & 55^{\prime} & 063^{\prime \prime} \\
28^{\circ} & 56^{\prime} & 212^{\prime \prime}\end{array}$ & $\begin{array}{l}41.0 \\
52.0\end{array}$ & $\begin{array}{l}27.0 \\
24.0\end{array}$ & $\begin{array}{l}32.0 \\
24.0\end{array}$ & $\begin{array}{l}\text { Clay loam } \\
\text { Sandy clay }\end{array}$ \\
\hline
\end{tabular}

Table (2). Physical and chemical properties of soils at different sites.

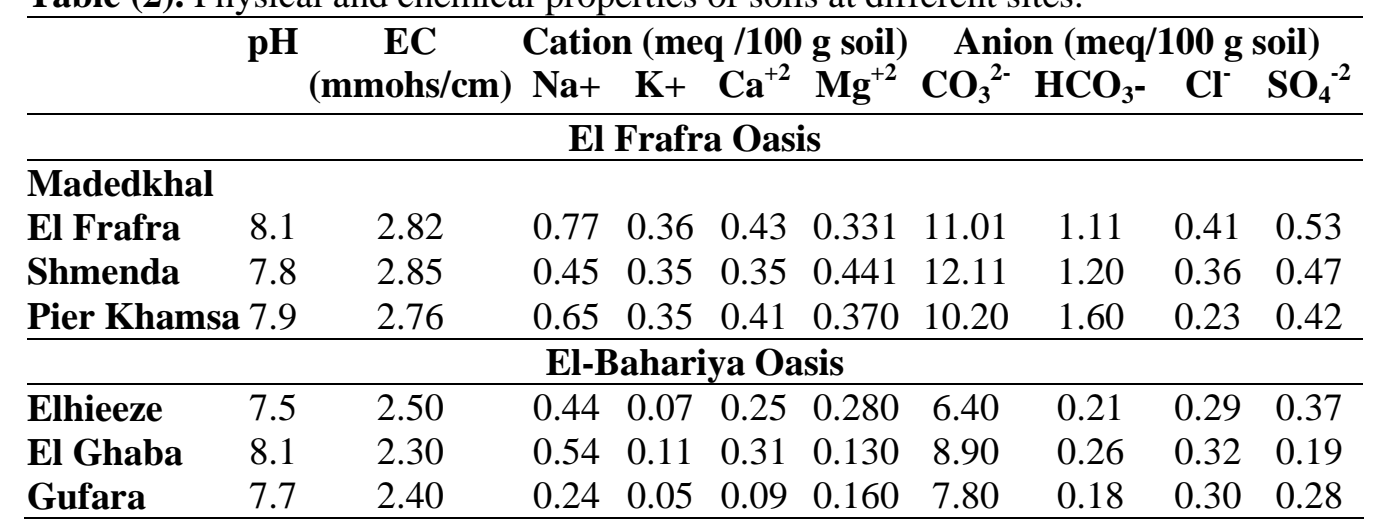

Statistical analysis was done by using one way ANOVA and Duncan test $(P<0.05)$ according to Snedecor and Cochran $(1990)$ to compare differences, where small letters in the same column indicated significantly different $(P<0.05)$ using the computer program of CoStat $(1990)$. 


\section{RESULTS AND DISCUSSION}

\section{Biological Effect of Bindweed Root Exudates}

As expected, the exudates extract at 1500 and $2000 \mu \mathrm{g} \mathrm{ml}^{-1}$ achieved significant suppression of fresh weights by 51.03 and $59.6 \%$ ( $L$. sativa), 60.71 and $73.43 \%$ ( $P$. paradoxa), respectively, compared to its control treatment. The calculated $\mathrm{EC}_{50}$ of bindweed root exudate extracts in the tested plant biomass weights were 1625 (L. sativa) and $1360 \mu \mathrm{g} / \mathrm{g}(P$. paradoxa), and the phytotoxicity depended on allelochemicals concentration and were increased with increasing exudates concentration in both $L$. sativa crop and $P$. paradoxa weed growth parameters, as shown in Fig. (1 and 2).

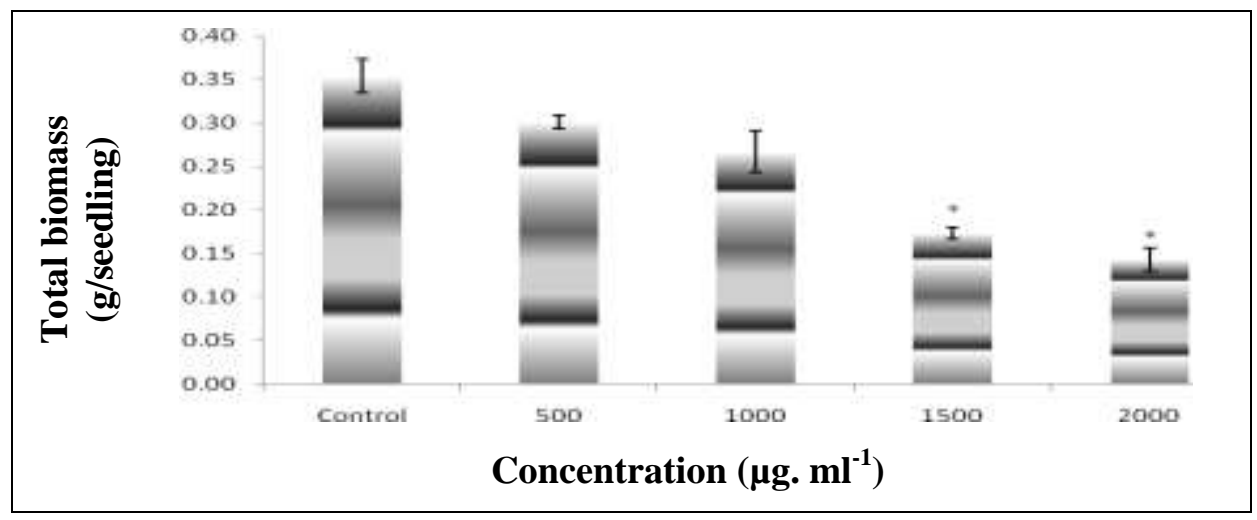

Fig. (1). Phytotoxic effects of bindweed root exudates upon total fresh weight (gm/plant) of $L$. sativa seedling.

The error bars means the standard deviations between replicates.

(*) means this treatment is significant at 0.05 level of probability.

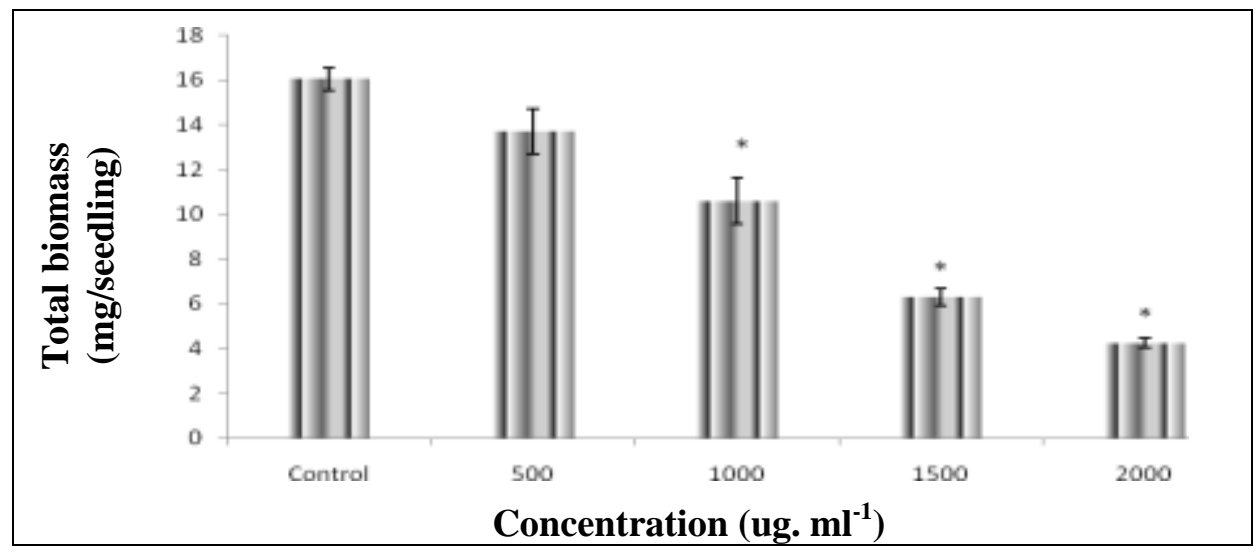

Fig. (2). Phytotoxic effects of bindweed root exudates upon total biomass fresh weight (mg/plant) of $P$. paradoxa seedling.

The error bars means the standard deviations between replicates.

Egyptian J. Desert Res., 65, No. 1, 31-46 (2015) 
(*) means this treatment is significant at 0.05 level of probability.

In filter paper technique, the bindweed extract at $2000 \mu \mathrm{g} \mathrm{ml}^{-1}$ showed the highest inhibitory effect upon root length (91.7\%), shoot length $(80.3 \%)$ and germination $(82.6 \%)$. A significant inhibition was shown at $1000 \mu \mathrm{g} \mathrm{ml}^{-1}$ concentration that resulted in $66.7,73.3$ and $69.6 \%$ suppression of root length, shoot length and germination, respectively, as compared to the control (Fig. 3).

In general, the results exhibited a highly positive response appeared in root elongation pronounced than others growth parameters to bindweed exudate allelochemicals, whereas the inhibition effect increased by increasing extract concentrations (Fig. 3). The present findings are in line with the earlier report of Fateh et al. (2012) who found that the allelopathic effect of bindweed in germination and seedling growth of millet and basil was proportional to the concentration of the extract.

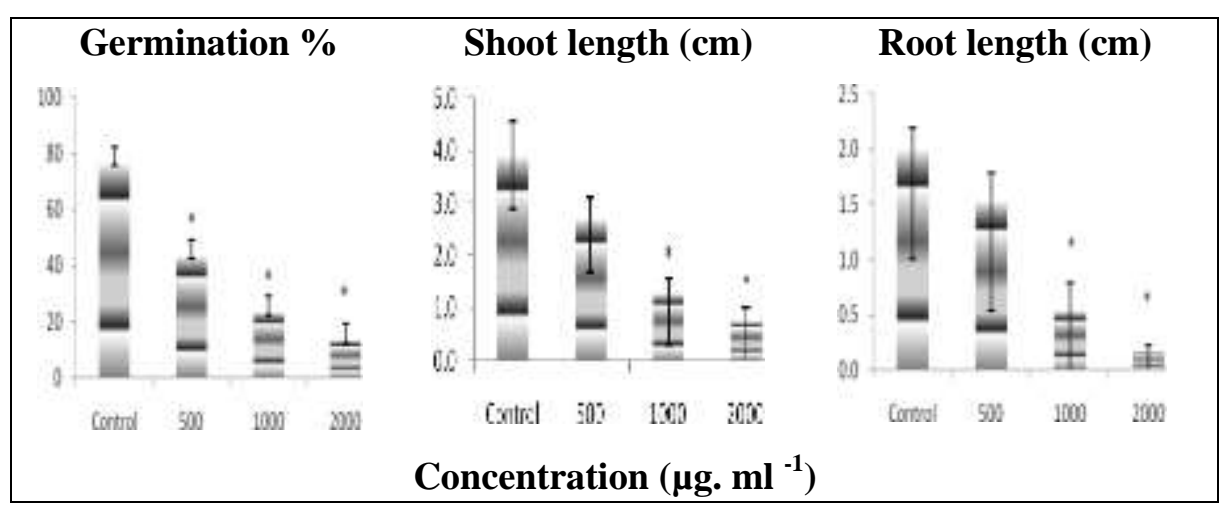

Fig. (3). Phytotoxic effects of bindweed root exudates upon germination and seedling growth of $P$. paradoxa.

The error bars means the standard deviations between replicates.

(*) means this treatment is significant at 0.05 level of probability.

\section{Activity of Bindweed Exudates on Microbes Count}

The number of the total microbial counts for both bacteria and fungi, as evident, were higher in rhizosphere soil than the non rhizosphere soil in both HD and LD of bindweeds (Table 3 and 4). These tables showed that the variations are even greater in soil fungi and bacteria total counts among investigated soils. At HD of bindweeds, a significant reduction was observed in the total counts of both bacteria and fungi than the LD area. Nevertheless, minor reductions in microbial total counts were observed in non rhizosphere soils at HD than the LD of bindweeds. The lowest fungi total numbers $\left(5.33 \times 10^{3}\right.$ and $\left.7.33 \times 10^{3}\right)$ was found in Pier Khamsa in HD and $\mathrm{LD}$, respectively in rhizosphere soils over other sites. Nevertheless, the lowest count of bacteria was observed in Shmenda and El Ghaba rhizosphere soil $\left(8.00 \times 10^{8}\right.$ and $\left.7.33 \times 10^{8}\right)$. The variation in total microbial counts was 
even greater in LD than HD areas in both rhizosphere and non rhizosphere soil. It could be concluded that bindweed root exudates exhibit marked effects on total microbial counts at rhizosphere soil and it may be regulating the microbial count in the rhizosphere.

Table (3). Total numbers of fungi (CFU/g) regardless of bindweed root exudates.

\begin{tabular}{|c|c|c|c|c|}
\hline & \multicolumn{2}{|c|}{ Low $\left(<20\right.$ plants $\left./ \mathrm{m}^{2}\right)$} & \multicolumn{2}{|c|}{ High density $\left(>20 \mathrm{~m}^{2}\right)$} \\
\hline & $\begin{array}{c}\text { Rhizosphere } \\
\text { soil }\end{array}$ & $\begin{array}{c}\text { Non rhizosphere } \\
\text { soil }\end{array}$ & $\begin{array}{c}\text { Rhizosephere } \\
\text { soil }\end{array}$ & $\begin{array}{c}\text { Non rhizosphere } \\
\text { soil }\end{array}$ \\
\hline & Mean $\times 10^{*^{3}}$ & Mean $\times 10^{*^{3}}$ & Mean $\times 10^{*^{3}}$ & mean $\times 10^{*^{3}}$ \\
\hline Madkhal El & & & & \\
\hline Frafra & 7. $33^{\mathrm{a}} \pm 0.58$ & $5.00^{\mathrm{a}} \pm 1.00$ & $6.00^{\mathrm{a}} \pm 1.00$ & $5.67^{\mathrm{a}} \pm 0.58$ \\
\hline Shmenda & $7.67^{\mathrm{a}} \pm 0.58$ & $5.00^{\mathrm{a}} \pm 1.00$ & $6.33^{\mathrm{b}} \pm 1.15$ & $4.67^{\mathrm{a}} \pm 0.58$ \\
\hline Pier Khamsa & $7.33^{\mathrm{a}} \pm 0.58$ & $5.17^{\mathrm{a}} \pm 0.58$ & $5.33^{a} \pm 0.58$ & $5.67^{\mathrm{b}} \pm 0.58$ \\
\hline Elhieeze & $8.00^{b} \pm 1.00$ & $5.33^{\mathrm{a}} \pm 1.53$ & $6.67^{\mathrm{a}} \pm 0.58$ & $5.00^{\mathrm{a}} \pm 1.00$ \\
\hline El Ghaba & $8.67^{b} \pm 0.58$ & $5.33^{\mathrm{a}} \pm 1.53$ & $6.00^{\mathrm{a}} \pm 1.00$ & $6.00^{\mathrm{b}} \pm 1.00$ \\
\hline Gufara & $8.00^{\mathrm{b}} \pm 1.00$ & $4.50^{\mathrm{a}} \pm 1.00$ & $6.33^{\mathrm{b}} \pm 0.58$ & $5.00^{\mathrm{a}} \pm 1.00$ \\
\hline $\operatorname{LSD}(0.05)$ & 0.299 & NS & 0.527 & 0.984 \\
\hline
\end{tabular}

Means followed by different letters are significant at 0.05 level of probability.

Table (4). Total numbers of bacteria (CFU/g) regardless of bindweed root exudates.

\begin{tabular}{|c|c|c|c|c|}
\hline & \multicolumn{2}{|c|}{ Low $\left(<20\right.$ plants $\left./ \mathrm{m}^{2}\right)$} & \multicolumn{2}{|c|}{ High density (>20 m2) } \\
\hline & $\begin{array}{l}\text { Rhizosphere } \\
\text { soil }\end{array}$ & $\begin{array}{l}\text { Non rhizosphere } \\
\text { soil }\end{array}$ & $\begin{array}{c}\text { Rhizosphere } \\
\text { soil }\end{array}$ & $\begin{array}{c}\text { Non rhizosphere } \\
\text { soil }\end{array}$ \\
\hline & Mean $\times 10^{8}$ & Mean $\times 10^{*} 8$ & Mean $\times 10^{* 8}$ & Mean $\times 10^{* 8}$ \\
\hline $\begin{array}{l}\text { Madkhal El } \\
\text { Frafra }\end{array}$ & $9.67^{\mathrm{a}} \pm 1.15$ & $8.33^{\mathrm{ab}} \pm 0.58$ & $8.00^{\mathrm{a}} \pm 1.00$ & $7.33^{b} \pm 1.53$ \\
\hline Shmenda & $8.00^{\mathrm{a}} \pm 1.00$ & $8.00^{\mathrm{ab}} \pm 1.00$ & $8.00^{\mathrm{a}} \pm 2.00$ & $7.33^{\mathrm{a}} \pm 1.53$ \\
\hline Pier Khamsa & $10.00^{\mathrm{b}} \pm 1.00$ & $8.33^{\mathrm{ab}} \pm 0.58$ & $8.67^{b} \pm 0.58$ & $8.00^{\mathrm{a}} \pm 2.00$ \\
\hline Elhieeze & $9.67^{\mathrm{a}} \pm 2.08$ & $8.67^{b} \pm 0.58$ & $7.33^{\mathrm{a}} \pm 1.53$ & $6.33^{\mathrm{a}} \pm 1.53$ \\
\hline El Ghaba & $9.00^{\mathrm{a}} \pm 1.00$ & $7.33^{\mathrm{a}} \pm 0.58$ & $8.67^{b} \pm 1.15$ & $7.00^{\mathrm{b}} \pm 1.00$ \\
\hline Gufara & $9.67^{\mathrm{a}} \pm 1.53$ & $8.00^{\mathrm{ab}} \pm 1.00$ & $8.00^{\mathrm{a}} \pm 2.00$ & $7.67^{\mathrm{a}} \pm 1.53$ \\
\hline $\operatorname{LSD}(0.05)$ & 1.281 & 0.863 & 0.873 & 0.754 \\
\hline
\end{tabular}

\section{Total phenols in rhizosphere and non rhizosphere soils}

During bindweeds flowering stage, phenols in both rhizosphere and non rhizosphere soil were colorimetrically determined, where the amount of total phenols reached 0.70 to 0.90 and 0.30 to $0.57 \mathrm{mg} / \mathrm{g}$ soil, respectively. The concentrations of these phenolic compounds were higher in sandy soils than the clay soils, as observed in El-frafra oasis than in El-bahria oasis, 
respectively (Table 1 and 2). The difference in phenols quantity was clearly higher in rhizosphere than non rhizosphere soil, as the calculated amount ranged from 34.9 to $23.7 \%$, estimated as the initial amounts in El-frafra and El-bahria oasis, respectively. These results could be attributed to the activity of plant roots though an interaction with microbes and other plants, which markedly occurred in the rhizosphere than non rhizosphere soils (Fig. 4).

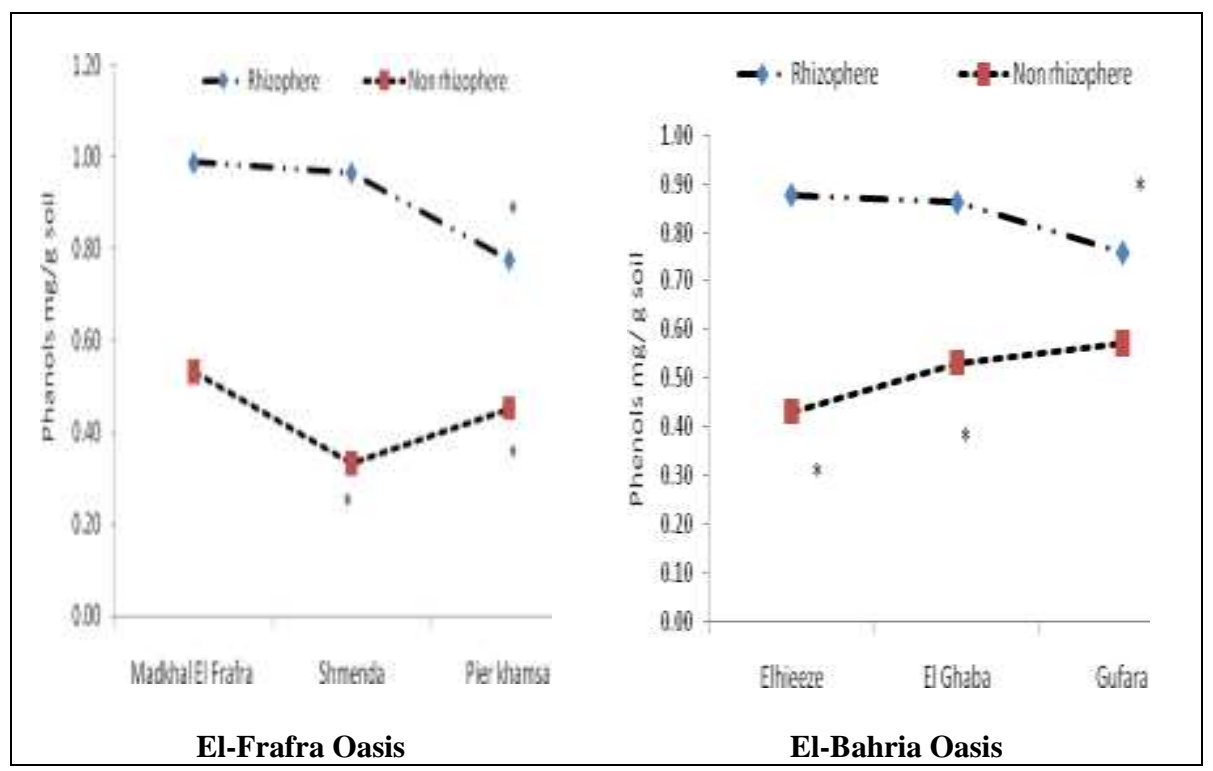

Fig. (4). Total phenols in bindweeds rhizosphere and non rhizosphere soil measured at flowering stage at different sites.

(*) means this treatment is significant at 0.05 level of probability.

\section{The Identification of Allelochemicals in Root Exudates of Bindweed}

The profile showed that more than six compounds were found in ethyl acetate extract. The first identified compound appeared at Rt: $27.2 \mathrm{~min}$ has molecular weight of 162 deduced from $\mathrm{m} / \mathrm{z} 163[\mathrm{M}+1]$ and $\lambda_{\max } 381$, might be umbelliferone, which has the molecular formula $\mathrm{C}_{9} \mathrm{H}_{6} \mathrm{O}_{3}$. The second compound corresponding to molecular weight of 304.2 and $\lambda_{\max } 381$ deduced from $\mathrm{m} / \mathrm{z} 304.2[\mathrm{M}+2]$, might be quercetin $\mathrm{C}_{15} \mathrm{H}_{10} \mathrm{O}_{7}$, which appeared on LC profile at Rt: $29.02 \mathrm{~min}$. The third compound present in the profile at Rt: $30.0 \mathrm{~min}$ had fragment ion at $\mathrm{m} / \mathrm{z} 317.1[\mathrm{M}+\mathrm{H}]$, have $\kappa_{\max } 351$ and molecular weight of 316.1 might be gentisic acid glycoside. The fourth compound presented in the $\mathrm{LC} / \mathrm{UV}$ profile at $31.60 \mathrm{~min}$ had formed fragment at $\mathrm{m} / \mathrm{z} 330[\mathrm{M}+\mathrm{H}]$, had $\lambda_{\max } 381$ and molecular weight of 329 might be coumaric acid glycoside. The fifth one had Rt 32.24 min gave protonated molecule ions at $\mathrm{m} / \mathrm{z} 314.1$ and $\lambda_{\max } 381.2$ might be vanillic glycoside. The last compound appeared on LC profile at Rt: $36.11 \mathrm{~min}$, deduced from $\mathrm{m} / \mathrm{z} 359.1$, had $\lambda_{\max } 381.2$ and molecular ions of 358.1, that 
could be conclusively identified as ferulic glycoside. These root exudates belonging to phenolic compounds may be responsible for bindweed root exudates activity against both microbes and test plants (Fig. 5 and 6). To examine bindweed exudates, several methods were employed to collect root exudates allelochemicals in MS medium and centrifuged to remove debris and lyophilized in freeze dryer, consequently dissolved in distilled water and extracted by partitioning with ethyl acetate after adjusting $\mathrm{pH} \leq 4$ (Walker et al., 2003 and Apricio et al., 2008), then the extract was evaporated to dryness and dissolved in ethanol for bioassay against $L$. sativa and $P$. paradoxa total biomass, which choose due to their phytotoxin sensitivity (Macias, 2010 and Omer and Balah, 2011). The result revealed that the growth of plant and microbes depend on each other and may be regulating underground chemical signals. However, this relationship is poorly understood in their community (Hawes et al., 2000). Recent evidence showing the resident bindweed root exudation had an active role in both neighbor plants and microbes maintain and regulation though accumulation of many compounds and function within their rhizosphere soils. Field examination was conducted in the infested area with bindweeds to clarify the role of their roots exudates in microbe structure and numbers in rhizosphere and non rhizosphere soils. These results are in harmony with Shi et al. (2011) who revealed that root exudates play a key role in plantmicroorganism interactions by influencing the structure and function of soil microbial communities.

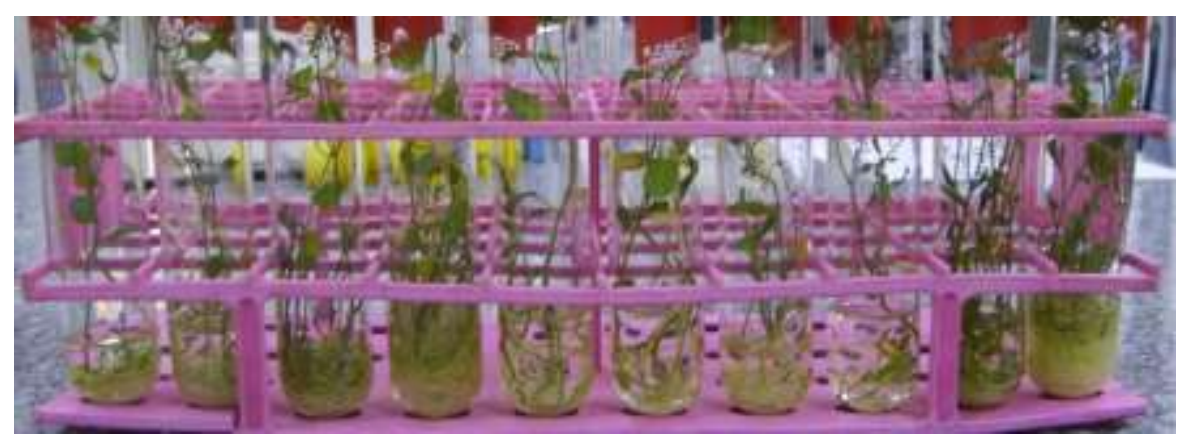

Fig. (5). Bindweeds root exudates feature after 28 days in MS medium under laboratory conditions.

The obtained results reflect the marked quantity of root exudates, which may affect soil characteristics. Fawzy et al. (2013) investigated allelopathic effect of shoots and roots of Convolvulus arvensis at the various concentrations on the soil algal diversity. These results have been supported by Milleret et al. (2009), who revealed that soil structure is engineered by a complex soil-plant-microbe interaction, meanwhile root-induced the increase in soil pore volume, whose magnitude could not be attributed to root-drilling 
effect, thus suggesting an indirect effect via microbial activity enhanced by root exudates.

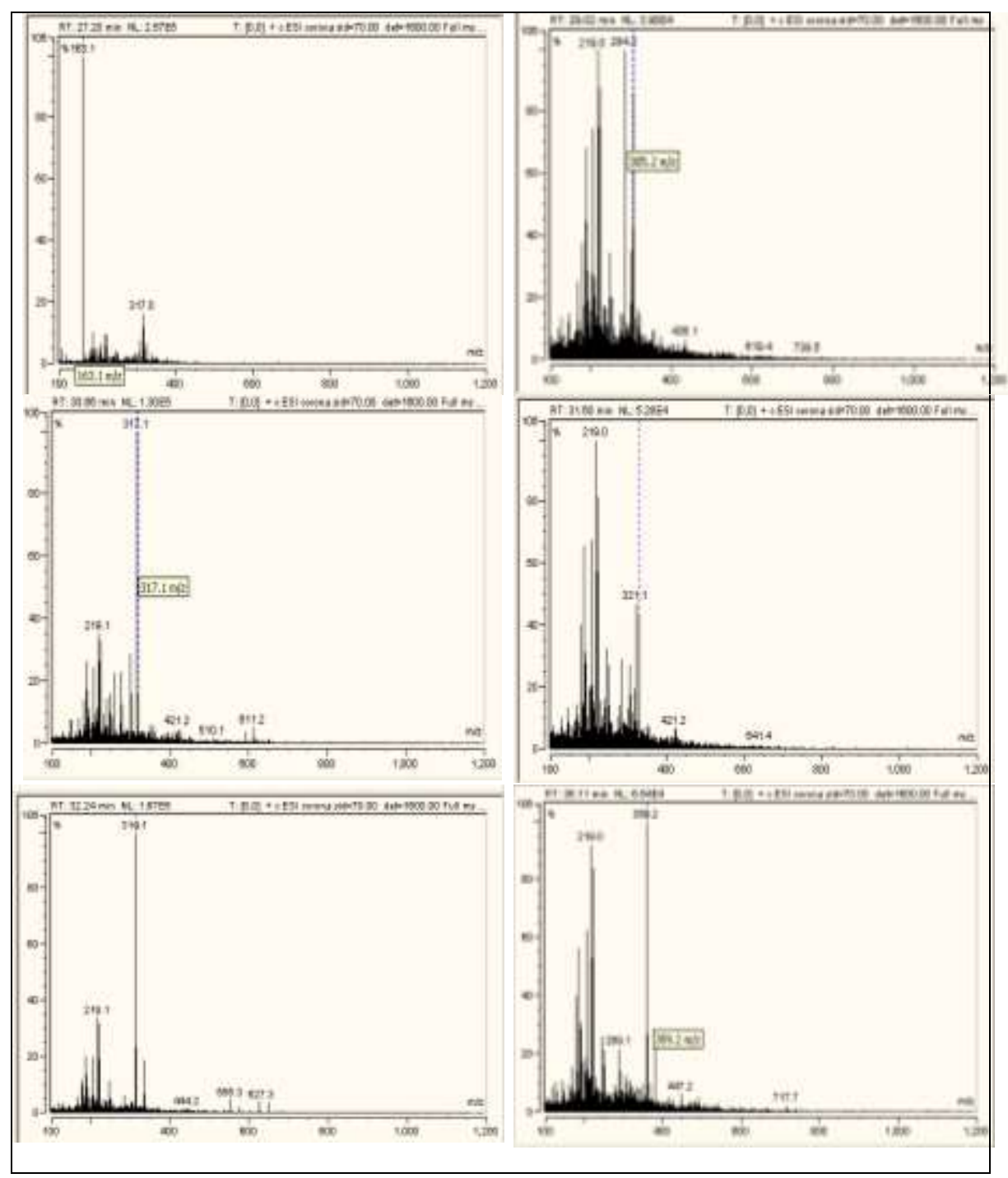

Fig. (6). The metabolic profiles of bindweed $C$. arvensis root exudates as determined through LC-MS.

The study provides the evidence of the phytotoxic potential of ethyl acetate root exudates extracts, which had higher activity in $P$. paradoxa than $L$. sativa seedling growth that could be due to the presence of phenolic compounds. The isolated signaling molecules may be responsible of the activity against inhabitant plant and microorganisms. Li et al. (2010) mentioned that phenolic allelochemicals have been observed in both natural 
and managed ecosystems, where they cause a number of ecological and economic problems, such as declines in crop yield due to soil sickness, regeneration failure of natural forests, and replanting problems in orchards. The rhizosphere soils had more quantity of microorganisms than non rhizosphere soil. Root exudates are also known to play important roles in a number of plant-microbial associations with the legume-Rhizobium symbiosis with leguminous roots (Janczareck et al., 1997). Soil microbes can have a profound influence on individual plants, plant communities and ultimately the ecosystem (Callaway et al., 2004). Allelochemicals may affect soil and crop processes, including soil fertility, nitrogen transfer, weed control, crop compatibility within rotations, plant growth and the maintenance of disease suppressive soils (Einhellig, 1995). The growth and performance of roots are significantly influenced by microbes colonizing the rhizosphere, including bacteria, fungi and nematodes. These root-microbe interactions can be beneficial, neutral or detrimental to the host plant (Mathesius, 2009). Plant phenolic acids (PAs) are extremely important in the soil $\mathrm{C}$ cycle, soil aggregation and in the formation of stable $\mathrm{C}$, and measurement of soil ester linked PA composition can provide an index of plant-derived $\mathrm{C}$ in soil (Martens, 2002b). The bindweeds exudates allelopathic activity could be caused by allelochemicals quantities and a vast array compounds that have remarkable metabolic feature to secreted metabolites of their roots. Based on these results bindweeds ( $C$. arvensis) is found to be highly suppressive weeds in both plants and microorganism and it also contains a wide range of constituents that needs to be explored under different stress conditions, and its performance should be tested separately against both microbe taxa and infested crops.

\section{REFERENCES}

Apricio, F.N., A. Evidente, P.R. DE-Luquea and D. Rubiales (2008). Fenugreek root exudates show species-specific stimulation of Orobanche seed germination. Weed Research, 48:163-168.

Aulakh, M.S., R. Wassmann, C. Bueno, J. Kreuzwieser and H. Rennenberg, (2001). Characterization of root exudates at different growth stages of ten rice (Oryza sativa L.) cultivars. Plant Biology, 3: 139-148.

Bertin, C., X.H. Yang and L.A. Weston, (2003). The role of root exudates and allelochemicals in the rhizosphere. Plant and Soil, 256: 67-83.

Black, C.A. (1973). In "Methods of Soil Analysis: Physical and Properties Including Statistics of Measurement and Sampling". Amer. Soc. Agron. Inc., Publ., Madison, Wisconsin, USA.

Callaway, R.M., G.C. Thelen, A. Rodriguez and W.E. Holben (2004). Soil biota and exotic plant invasion. Nature, 427: 731-733.

Egyptian J. Desert Res., 65, No. 1, 31-46 (2015) 
Callihan, R.H., C.V. Eberlein, J.P. McCaffrey and D.C. Thill. (1990). In "Field Bindweed: Biology and Management". University of Idaho, Cooperative Extension System, College of Agriculture Bulletin, \#719.

Chiang, K.Y., Y.N. Wang, M.K. Wang and P.N. Chiang (2006). Lowmolecular-weight organic acids and metal speciation in rhizosphere and bulk soils of a temperate rain forestin chitou, Taiwan. Taiwan. J. For. Sci., 21(3): 327-37.

CoStat Software (1990). In "Microcomputer Program Analysis". Version 4.2, CoHortSofware, Berkeley, CA.

Einhellig, F.A. (1995). In "Allelopathy: Current Status and Future Goals". (Inderjit, Dakshini, K.M.M., Einhellig, F.A. (Eds.). Allelopathy: Organisms, Processes and Applications. ACS Symposium Series, Washington, DC, p. 1-25.

Fateh, E., S.S. Sohrabi and F. Gerami, (2012). Evaluation the allelopathic effect of bindweed (Convolvulus arvensis L.) on germination and seedling growth of millet and basil. Advances in Environmental Biology, 6: 940-950.

Fawzy, M.A., A.F. Hifney, A.A. Issa. and G. Gamal (2013). Phytochemical constituents and allelopathic effects of some medicinal plants extract on the soil algal diversity. Journal of Agricultural Science and Technology A, 3(12): 1000-1009.

Frazier, J.C. (1943). Food reserve depletion and synthesis in field bindweed, Convolvulus arvensis L., as related to 7-day and 14-day intervals of cultivation. Plant Physiology, 18:315-323.

Gray, A. (1970). In "Gray's Manual of Botany; A Handbook of the Flowering Plants and Ferns of Central and Northeastern United States and Adjacent Canada". 8th ed. D. VanNostrand Co., New York.

Grayston, S.J., D. Vaughan and D. Jones (1996). Rhizosphere carbon flow in trees, in comparison with annual plants: the importance of root exudation and its impact on microbial activity and nutrient availability. Applied Soil Ecology, 1: 29-56.

Hawes, M.C., U. Gunawardena, S. Miyasaka and X. Zhao (2000). The role of root border cells in plant defense. Trends Plant Sci., 5: 128-133

Hegab, M.M. and G.R. Ghareib (2010). Methanol extract potential of fieldbindweed (Convolvulus arvensis L.) for wheat growth enhancement. International Journal of Botany, 6: 334-342.

Hegnauer, R. (1964). Die Chemotaxonomie der Pflanzen Birkhauser Verlag, Basel., 3: 547-561.

Holm, L., D.L. Plunknett, J.V. Pancho and J.P. Herberger (1977). In "The Worlds Worst Weeds: Distribution and Biology". University Press of Hawaii, Honolulu. 
Janczareck, M., T.U. Sypniewska and A. Skorupska (1997). Effect of authentic flavonoids and the exudate of clover roots on growth rate and inducing ability of nod genes of Rhizobium leguminosarum. Microbiol. Res., 152: 93-98.

Johnson, L.F., E.A. Curl, J.H. Band and H.A. Fribourg (1959). Methods for studying soil Microflora-plant disease relationships. Burgess, Minneapolis, p. 12-20.

Li, Z.H., Q. Wang, X. Ruan, C.D. Pan and D.A. Jiang (2010). Phenolics and plant allelopathy. Molecules, 15: 8933-8952.

Macias, F.A. (2010). Isolation and phytotoxicity of terpenes from Tectona grandis. J. Chem. Ecol., 36: 396-404.

Maff (1957). In "Bindweeds". MAFF Advisory Leaflet 450, HMSO, London, UK.

Martens, D.A. (2002a). Identification of phenolic acid composition of alkaliextracted plants and soils. Soil Sci. Soc. Am. J., 66: 1240-1248.

Martens, D.A. (2002b). Relationship between plant phenolic acids released during soil mineralization and aggregate stabilization. Soil Sci. Soc. Am. J., 66: 1857-1867.

Mathesius, U. (2009). Comparative proteomic studies of root-microbe interactions. Journal of Proteomics, 72: 353-366.

Maw, M.G. (1984). In "Convolvulus arvensis L., Field Bindweed (Convolvulaceae)". Biological Control Programmes Against Insects and Weeds in Canada, 1969 - 1980 (Kelleher, J.S. and M.A. Hulme eds.). Common Wealth Agricultural Bureaux, Slough, p. 155-157.

Milleret, R., C. Le Bayon, F. Lamy, J.M. Gobat and P. Boivin (2009). Impact of root, mycorrhiza and earthworm on soil physical properties as assessed by shrinkage analysis. Journal of Hydrology, 373: 499-507.

Murashige, T. and F. Skoog (1962). A revised medium for rapid growth and bioassays with tobacco tissue cultures. Physiologia Plantarum, 15: 473-497.

Omer, A.M. and M.A. Balah (2011). Using of rhizo-microbes as bioherbicides of weeds. Global J. Biotech. Biochem., 6(3): 102-111.

Parkinson, P., T.R.G. Gray and S.T. William (1971). In "Methods for Studying the Ecology of Soil Microorganisms". Blackwell Scientific Publication Oxford, $116 \mathrm{pp}$.

Paynel, F., J. Murray and J.B. Cliquet (2001). Root exudates: a pathway for short-term $\mathrm{N}$ transfer from clover and ryegrass. Plant and Soil, 229: 235-243.

Richards, L.A. (1954). In "Diagnosis and Improvement of Saline and Alkali Soils". USDA Handbook No. 60, Washington, DC, USA.

Schwab, S.M., J.A. Mence and R.T. Leonard (1983). Quantitative and qualitative effects of phosphorus on extracts and exudates of

Egyptian J. Desert Res., 65, No. 1, 31-46 (2015) 
sudangrass roots in relation to vesicular-arbuscular mycorrhiza formation. Plant Physiology, 73: 761-765.

Serap, S., Y. Nalan, A. Ozkan and A. Guleray (2013). Determination of the genotoxic effects of Convolvulus arvensis extracts on corn (Zea mays L.) seeds. Toxicology and Industrial Health, 29(5): 449-59.

Shi, S., A.E. Richardson, M.O. Callaghan, K.M. DeAngelis, E.E. Jones, A. Stewart, M.K. Firestone and L.M. Condron (2011). Effects of selected root exudates components on soil bacterial communities. FEMS Microbiol Ecol., 77(3): 600-610.

Swan, D.G. (1980). Field bindweed, Convolvulus arvensis L. Washington State University, College of Agriculture Research Center, Bulletin \#0888.

Snedecor, G.W. and W.G. Cochran (1990). In "Statistical Methods". $8^{\text {th }}$ Ed. Iowa State Univ. Press, Ames, Iowa, U.S.A.

Tâckholm, V. (1974). In "Students Flora of Egypt". 2nd Ed. Published by Cairo University, Printed by Cooperative Printing Company, Beirut.

Tepfer, D., A. Goldmann, N.M. Pamboukdjia Maille, A. Lepingle, D. Chevalier, J. Denarie and C. Rosenberg (1988). A plasmid of Rhizobium meliloti 41 encodes catabolism of two compounds from root exudate of Calystegium sepium. Journal of Bacteriology, 170: 1153-1161.

Timmons, F. L. (1949). Duration of viability of bindweed seed under field conditions and experimental results in the control of bindweed seedlings. Agronomy Journal, 41(3): 130-133.

Todorov, I.V., M.I. Simeonovsky, V.M. Baltiyska and V.I. Stamenova (1994). Effect of physiologically active substances from overground and underground parts of Convolvulus arvensis L. on the early development of some cultivars (Solanum lycopersicum L., Raphanus sativus var. radicula, Lactuca sativa L., and Daucus carota L.). Botanika., 85: 245-51.

Walker, T.S., H.P. Bais, E. Grotewold and J.M. Vivanco (2003). Root exudation and rhizosphere biology. Plant Physiology, 132: 44-51.

Weaver, S.A. and W.R. Riley. (1982). The biology of Canadian weeds. 53. Convolvulus arvensis L. Canadian Journal of Plant Science, 62: 461472.

Wiese, A.F., C.D. Salisbury, B.W. Bean, M.G. Schoenhals and S. Amosson (1996). Economic evaluation of field bindweed (Convolvulus arvensis) control in a winter wheat-fallow rotation. Weed Science, 44: 622-628.

Wiese, A.F. and W.M. Phillips (1976). Field bindweed. Weeds Today, 7: 2223. 


\section{التأثيرات الأليلوباثية لراشح جذور العليق على النباتات وكائنات التربة الدقيقة}

محمد عبد العزيز أبو الخير بلح مركز بحوث الصحر اء- المطريةـ القاهرة- مصر البور

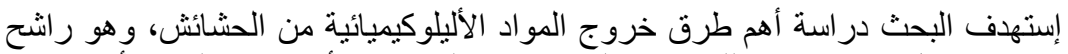

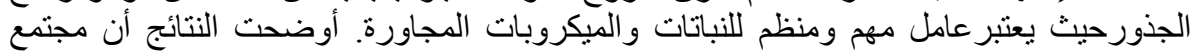

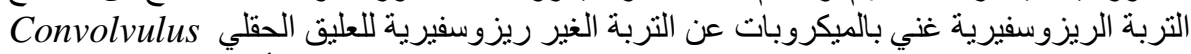
arvensis

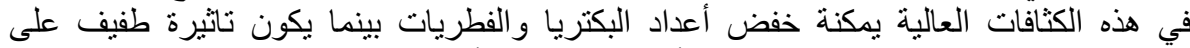

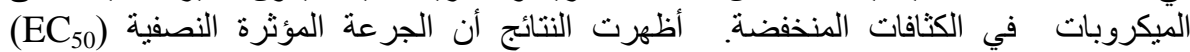

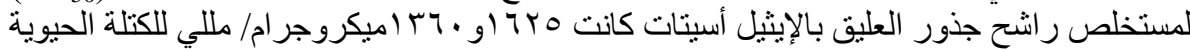

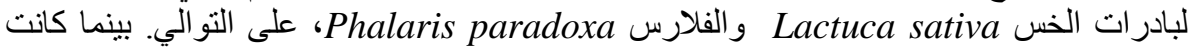

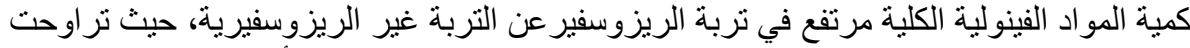

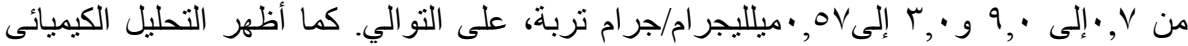
لمستخلص راشح الجذور وجود مركبات امبيلفيرون $\left(\mathrm{C}_{15} \mathrm{H}_{10} \mathrm{O}_{7}\right)$ و

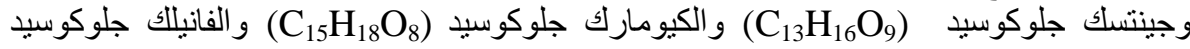
LC- والفريوليك جلوكوسيد (C) $\left(\mathrm{C}_{14} \mathrm{H}_{18} \mathrm{H}_{18} \mathrm{H}_{20}\right)$

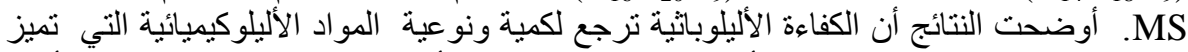

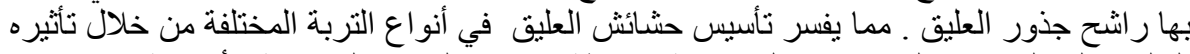
السلبى على النباتات و الميكروبات المصاحبة بو اسطة إثار ات الجذور الكيميائية الأرضية.

Egyptian J. Desert Res., 65, No. 1, 31-46 (2015) 